\title{
ENTOMOLOGY
}

\section{Checklist of the mosquito species from four Sicilian Islands: Lampedusa, Linosa, Ustica and Pantelleria}

\author{
L.Toma, ${ }^{1}$ F. Severini, ${ }^{1}$ R. Romi, ${ }^{2}$ M. Goffredo, ${ }^{3}$ A. Torina, ${ }^{4}$ M. Di Luca ${ }^{1}$ \\ ${ }^{1}$ Infectious Diseases Department, Vector-borne Diseases Unit, National Institute of Health, Rome; ${ }^{2}$ Amateur \\ Entomologist, Rome; ${ }^{3}$ Istituto Zooprofilattico Sperimentale dell'Abruzzo e del Molise 'G. Caporale', Teramo; ${ }^{4}$ Istituto \\ Zooprofilattico Sperimentale della Sicilia 'A. Mirri’, Palermo, Italy
}

\author{
Correspondence: Luciano Toma, Reparto di Malattie Trasmesse da \\ Vettori, Dipartimento di Malattie Infettive, Istituto Superiore di Sanità. \\ Viale Regina Elena, 299 - 00161 Rome, Italy. \\ Tel.: +39.06.49902301. \\ E-mail: luciano.toma@iss.it
}

Key words: mosquito distribution, Italy, minor islands, Sicily, vectors.

Acknowledgments: The authors would like to thank all the local Authorities and the inhabitants of the Lampedusa, Linosa, Pantelleria and Ustica islands for their kind hospitality, full support and their collaboration, pivotal in this study. The authors are grateful to Dr. Luigi Gradoni for helpful suggestions and to Dr Lesley Mills for her fundamental manuscript revision work.

Contributions: TL conceived and directed the study; DLM participated to the conception and design, of the study; TL, SF, DLM carried out collections and specimens identification; TA managed the network with local Authorities, before and during the study period and participated to the field activities; RR, and GM participated in drafting the article and performed interpretation of data, revising it critically in its intellectual content. All Authors gave final approval of the version to be submitted and any revised version.

Conflict of interest statement: The Authors declare they have no conflicts of interest.

Funding: The field activities on Ustica Island were carried out in the frame of the project "Rischio di introduzione e diffusione di virus trasmessi da vettori in Italia" (IZS AM 03/14 RC), funded by the Italian Ministry of Health. This study was supported by VectorNet and its funding agencies ECDC and EFSA (contract number OC/EFSA/ AHAW/2013/02). FS was partially funded by the European Commission Framework Program Seven Award "InfraVec" (project number 228421).

Received for publication: 16 March 2020.

Revision received: 30 June 2020.

Accepted for publication: 2 July 2020.

${ }^{\circ}$ Copyright: the Author(s), 2020

Licensee PAGEPress, Italy

Journal of Entomological and Acarological Research 2020; 52:8968 doi:10.4081/jear.2020.8968

This article is distributed under the terms of the Creative Commons Attribution Noncommercial License (by-nc 4.0) which permits any noncommercial use, distribution, and reproduction in any medium, provided the original author(s) and source are credited.

\begin{abstract}
The present study reports the results of the first survey of mosquito species in four of the minor Sicilian Islands, namely Lampedusa, Linosa, Pantelleria and Ustica. These surveys were carried out during field activities aimed at recording the occurrence of Aedes albopictus, now reported in all these territories. Adult mosquitoes were collected by traps or by handheld electric aspirators. Larval collections were performed using dippers and droppers. Samples were morphologically identified and molecular investigations were carried out when needed. A total of 6 species were found, namely Aedes (Stegomyia) albopictus, Culex (Culex) pipiens, Culex (Culex) laticinctus, Aedes (Ochlerotatus) mariae, Aedes (Ochlerotatus) zammitii, and Culiseta (Allotheobaldia) longiareolata, the first 2 of which are already a known health concern. This checklist of mosquito species shows the widespread occurrence of Culex laticinctus whose distribution in Italy has still not been thoroughly investigated, whose ecology is poorly known and whose competence as a vector of pathogens is unknown. In Pantelleria, we found larvae of an Aedes species worthy of further investigation.
\end{abstract}

\section{Introduction}

The southern Sicilian Islands are places of special biological interest because of their peculiar geographic position in the western Mediterranean Sea, representing the southernmost limit of Italy; they are the border between Europe and Africa. The information on mosquito fauna of the minor Sicilian islands available up to now has been rare and fragmentary. In order to fill this gap, the present study reports results of an entomological inquiry aimed at investigating the mosquito fauna on four minor Sicilian Islands: Lampedusa and Linosa (belonging to the Pelagian archipelago together with Lampione), Pantelleria and Ustica. The entomological field activities were partially funded and supported by VectorNet, a joint project with the European Food Safety Agency (EFSA) and the European Centre for Disease Prevention and Control (ECDC), aimed at implementing targeted entomological surveillance/monitoring in Europe and the area surrounding the Mediterranean Basin concerning Aedes albopictus (Skuse, 1894), carried out in 2015. In this regard, both the Istituto Superiore di Sanità (ISS) of Rome and the Istituto Zooprofilattico Sperimentale della Sicilia (IZS) of Palermo were 
involved in carrying out an entomological study on Lampedusa, Linosa and Pantelleria, during the summer of 2015 (Di Luca et al., 2017). The survey on the island of Ustica in 2017 was supported by the project funded by the Italian Ministry of Health, in which the ISS and the Istituto Zooprofilattico Sperimentale di Abruzzo e Molise (IZSAM) were involved and that allowed the first reporting of $A e$. albopictus on that island (Toma et al., 2017).

At present the only data available on mosquito fauna on the Sicilian islands are findings of Aedes zammitii (Theobald, 1903) (according to the classification by Wilkerson et al.) on Lampedusa (Coluzzi et al., 1974), Anopheles sergentii (Theobald, 1907) (D'Alessandro \& Saccà, 1967) on Pantelleria and the recent report of Ae. albopictus on the Pelagie Islands and Pantelleria (Di Luca et al., 2017). Moreover, studies carried out on the Maltese Archipelago (Gatt et al., 2009; Schaffner et al., 2010) describe the mosquito species composition in the closest overseas area to Sicily.

In such context the present study reports the first checklist of the Culicidae species of the islands of Lampedusa, Linosa, Pantelleria and Ustica.

As a consequence, via this survey, we provide data on mosquito species known to be possible vectors of pathogens, such as West Nile, Usutu, Chikungunya, Dengue or Zika arboviruses that could be accidentally introduced on these islands.

\section{Materials and Methods}

\section{Study area}

The study area consisted of the islands of Lampedusa, Linosa, Pantelleria and Ustica. (Figure 1A). Lampedusa, Linosa and Pantelleria, were visited during the summer of 2015, while Ustica was investigated in 2017. Lampedusa and Lampione belong geologically to the African continent, whereas Linosa and Pantelleria are of volcanic origin. Lampedusa and Linosa, with a total area of about $26 \mathrm{~km}^{2}$, belong to the Province of Agrigento. Two hundred and five $\mathrm{km}$ off the coast of Sicily, Lampedusa $\left(20.2 \mathrm{~km}^{2}\right.$ and $40 \mathrm{~km}$ of coastline) is the largest island of the Pelagie Archipelago and the southernmost territory of Italy. Lampedusa has fresh water from desalination only and its territory is characterized by two main facies with respect to the use of water. In fact, the eastern part, hosting the Lampedusa Municipality, supplies water for domestic use and for watering, and a wide variety of small water receptacles were located. The western part is flat and almost completely desert and the isolated residential houses have underground tanks for water storage. Cultivated land occupies areas protected from the strong winds, and fields surrounded by dry stone walls are typical on the island. Only three domestic livestock farms are present on the island, two sheep and goat farms and a horse riding stable. The island has 6000 inhabitants, increasing to about 45,000 with the arrival of tourists during the summer season. In Lampedusa the potential breeding site are limited to the urban centre, the cemetery and the Madonna di Porto Salvo Sanctuary. In the village of Lampedusa, breeding sites are essentially represented by manholes as these are often the only water receptacle in such contest. The resting sites for adult mosquitoes are represented mainly by situations of uncultivated vegetation and shaded areas with the presence of ornamental hedges and flowers outside commercial activities, such as restaurants. In the cemetery and in the Sanctuary, flower pots are the only breeding sites and scarce seem to be the resting situations for adult mosquitoes; moreover in the Sanctuary, there is also an ancient water well not easy to be inspected. The resting sites are the garden of the Sanctuary shaded by Ficus trees and also an ancient cave where mosquitoes find shade and coolness even in the hottest hours. Forty-two $\mathrm{km}$ from Lampedusa, Linosa is an island with an area of $3 \mathrm{~km}^{2}$, the highest elevation being Monte Vulcano (195 m a.s.1.). Here, the water supply for approximately 450 inhabitants is available only from tanks. In this island the rare breeding sites are represented by various containers to stock up on water for the vegetable gardens, such as jerry cans, tubs, buckets and watering cans. Equally rare are the resting sites occurring with shaded vegetation.

Lampione wasn't considered in this study as it is a very small isle $\left(0,036 \mathrm{~km}^{2}\right)$ completely uninhabited. Pantelleria (about 7700 inhabitants, increasing to more than 20,000 in summer) belongs to the Province of Trapani and extends for about $80 \mathrm{~km}^{2}$. The island, volcanic in origin, lies $110 \mathrm{~km}$ southwest of Sicily and $70 \mathrm{~km}$ northeast of Tunisia. It has a mountainous terrain, its highest peak being Montagna Grande ( $836 \mathrm{~m}$ a.s.1.), originating from a volcanic caldera, now covered by woods and maquis. Several thermal springs, containing silica and sodium carbonate, characterize Pantelleria where there is also a lake of brackish water of volcanic origin, called Specchio di Venere Lake. The lake contains meteoric and thermal spring water $\left(40-50{ }^{\circ} \mathrm{C}\right)$, rich in salt and sulphur compounds. The population is mostly concentrated in the three villages of Pantelleria, Khamma and Scauri, where water tanks supplied by a desalination plant represent the only source of drinking water. The climate is characterized by a long dry season
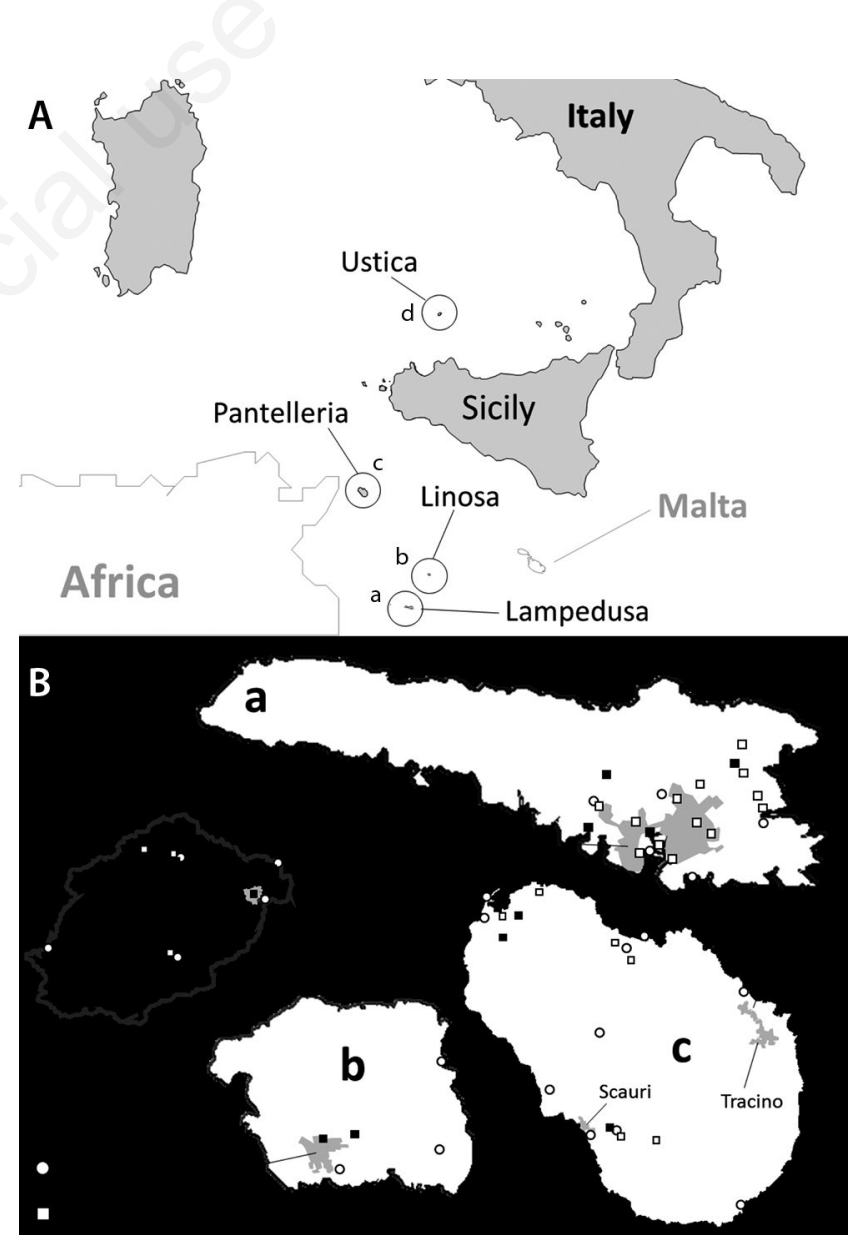

Figure 1. Map of the study area. A: geographical locations on the islands of Lampedusa (a), Linosa (b), Pantelleria (c) and Ustica (d) in the Mediterranean Sea. B: detail of the four islands showing locations of breeding sites (circle), adult traps (white square) and human landing catches (black square) during the entomological field study, July-October 2015 and May 2016. 
and strong winds throughout the year. Mediterranean maquis dominates the southeastern part of the island while pine forests grow on the highest peaks, which at lower altitudes are replaced by oak trees. Cultivation of vines and olive trees are very common. The horse riding stable is located near the lake while several domestic animal farms (stabling poultry, pigs, donkeys, cattle, sheep and goats), both intensive and household, are scattered on the island. The only kennel on the island is situated in the village of Pantelleria (Di Luca et al., 2017). In Pantelleria the breeding site are represented by manholes in the urban context even if the main variety of opportunities to lay eggs for mosquitoes is supplied in the country and in particular at the farms. In fact, here, the water stocked for vegetable gardens and for domestic animals is often colonized by mosquito larvae. Animal shelters, mainly the ones with low roofs for pigs and rabbits, are often used as resting sites for nocturnal mosquitoes.

Ustica $\left(38^{\circ} 43^{\prime} \mathrm{N} 13^{\circ} 11^{\prime} \mathrm{E}, 8 \mathrm{~km}^{2}, 1,359\right.$ inhabitants, 170 inhabitants $/ \mathrm{km}^{2}$ ), located about $66 \mathrm{~km}$ northwest of Sicily, is an island of volcanic origin. It has few streams, not only because of the scarce rainfall but also for its orography and geology that do not allow the permanence of water. Several small structures that were excavated in the past to supply water are still visible but have not been used since the desalinator was installed. Temporary ponds are also present on Ustica as rainwater collection in rocks, the best known of which is "Gorgo salato" which is located southwest of Punta Gorgo Salato. Two large concrete tanks used in the past as rainwater reserve to water domestic animals are present on the island. A certain amount of water always remains on the bottom of these structures representing a suitable opportunity for mosquito larval breeding. On all these islands, along the coast, the rock pools full of salt water are suitable larval breeding places for Aedes larvae, while adults rest in every crack and natural or artificial shelter. The biotope of the island of Ustica has considerable importance as it is located along the main migratory route of numerous species of birds. From a wildlife point of view, the island of Ustica is of particular ornithological importance as a resting place for numerous birds during the spring migration and above all in autumn. The climate of this part of the Mediterranean area is generally characterized by a short mild wet season and a long dry season.

\section{Mosquito collections}

During the summer and autumn of 2015 several surveys were carried out: on Lampedusa from $6^{\text {th }}$ to $9^{\text {th }}$, from $14^{\text {th }}$ to $18^{\text {th }}$ July and from $27^{\text {th }}$ to $30^{\text {th }}$ October; on Linosa a 6 hour survey was carried out on $28^{\text {th }}$ October; on Pantelleria from $12^{\text {th }}$ to $16^{\text {th }}$ and from $19^{\text {th }}$ to $22^{\text {th }}$ October; on Ustica from $21^{\text {st }}$ to $25^{\text {th }}$ May 2017. Although well planned in advance, all of the field activities carried out were affected by the contingency of the moment, in terms of characteristics of the area, length of stay, availability of the local personnel, the possibility of accessing private properties and climatic conditions. In general, mosquito collection sites on the islands were actively selected by looking for water collections for larval stages and vegetative coverage conditions and for the presence of domestic animals for adults.

Mosquitoes were collected with different methods. Adult mosquitoes were collected by using BG Sentinel ${ }^{\mathrm{TM}}$ traps baited with BG-Lure (Biogents, Regensburg, Germany) and CDC Miniature Light/ $\mathrm{CO}_{2}$ baited Trap. On Lampedusa 13 traps (6 CDC and 7 BGSentinel) were set, 6 traps (3 CDC and 3 BG-Sentinel) on Pantelleria and 3 traps on Ustica (2 CDC and 1 BG-Sentinel) (Figure 1B). On Lampedusa as well on Pantelleria, when possible, specimens were directly aspirated on vegetation or while landing on exposed skin by handheld electric aspirators. During the survey on Ustica, two CDC traps were used for adult mosquito collection. The active search for water collections and places suitable for the presence of mosquitoes, took up most of the day about 5 hours in the morning and 5 hours in the afternoon until sunset) also including the selection for the sites in which to place the mosquito traps.

The traps were set in farms with an occurrence of domestic animals (mainly goats, equines and poultry), with the exception of the site of the Madonna di Porto Salvo Sanctuary on Lampedusa. In fact, here we set one of each type of trap as in that site, the local conditions (a cave, shady vegetation and an ancient water well) were suitable for mosquitoes. During each survey the traps worked for 1-3 days and all samples were then transferred to the laboratories of ISS and IZS for further analyses. On the island of Linosa, no trap was used because of the brevity of the survey imposed by the timetable of the ferries connecting with Lampedusa. Larval collections were performed using dippers and droppers by inspecting as many artificial containers (removable or nonremovable) as possible or natural water receptacles as potential larval breeding sites. When possible, small containers filled with water, such as vases, saucers and buckets, were emptied by filtering the mosquito larvae by using a strainer. Gathered larvae were preserved in alcohol and egg-rafts, when found, were allowed to hatch for larval rearing in the insectarium. The total collection efforts for each island are reported in Table 1.

\section{Mosquito identification and molecular analysis}

Larvae and adults were morphologically identified using the keys for Italian and European mosquito species (Severini et al., 2009; Romi et al., 1997; Schaffner et al., 2001). Egg rafts found in the field were maintained to allow hatching and larvae were reared until the fourth instar or adulthood (Pierdominici et al., 1984; Becker et al., 2010) for specimen counts and for morphological identification. The specimens collected on the islands were mainly identified by morphology. To discriminate the species, molecular analyses were carried out on specimens belonging to Aedes mariae complex and on instar larvae of Aedes sp. using ITS-2 marker (Marinucci et al., 1999; Di Luca et al., 2005) and on specimens of Culex pipiens (L.) and Culex laticinctus Edwards, 1913 using COI (Folmer et al., 1994). PCR products were sequenced at Eurofins

Table 1. Efforts used in the field activities. Number and type of trap are reported together with time spent in field work and trap operating (days and hours).

\begin{tabular}{|c|c|c|c|c|c|}
\hline \multirow[t]{2}{*}{ Island } & \multicolumn{2}{|c|}{ CDC-Trap } & \multicolumn{2}{|c|}{ BG-Trap } & \multirow{2}{*}{$\begin{array}{c}\text { Direct collections } \\
\mathbf{h}\end{array}$} \\
\hline & No. & h & No. & h & \\
\hline LAM & 6 & 165 & 7 & 168 & 70 \\
\hline LIN & 0 & 0 & 0 & & 6 \\
\hline PAN & 3 & 120 & 3 & 120 & 50 \\
\hline UST & 2 & 72 & 0 & & 30 \\
\hline Total working hours & & 357 & & 288 & 156 \\
\hline
\end{tabular}


Genomics (Ebersberg Germany). The sequences obtained were analyzed by Accelrys Gene software (Accelrys Inc., San Diego, CA, USA) and identified by BLASTn search by comparing them with sequences available in the GenBank database.

\section{Results and Discussion}

During the surveys on the four islands, a total of 1379 larvae and 251 adult mosquitoes were collected. A total of 6 species belonging to 4 genera, namely Aedes (Stegomyia) albopictus (Skuse, 1897), Culex (Culex) pipiens (L.), Culex (Culex) laticinctus Edwards, 1913, Aedes (Ochlerotatus) mariae Sergent and Sergent, 1903 (according to the classification by Wilkerson et al.), Aedes (Ochlerotatus) zammitii (Theobald, 1903), and Culiseta (Allotheobaldia) longiareolata (Macquart, 1838). Results in terms of number of adults and larvae collected for each species per islands are reported in Table 2. The relative mosquito abundance for immatures and adults is reported in Table 3 and in Table 4 respectively. In general adults mosquitoes were not abundant due to the climatic and environmental conditions on all these islands. Nevertheless, the higher number of adult mosquitoes, resting or attempting the landing on humans were performed in Lampedusa not only because this was the most visited island but also for the presence on the shaded conditions at Madonna di Porto Salvo Sanctuary (Table 4).

In order to distinguish the members of the Ae. mariae complex collected on the four islands, a molecular analysis, using the sequencing of ITS-2 of the rRNA, was carried out. A 355-bp region was sequenced from 12 specimens from Lampedusa identifying

Table 2. Mosquito larvae and adults per island; total number (No.) and percentage (\%) on the total of collected specimens per species.

\begin{tabular}{|c|c|c|c|c|c|c|c|c|c|c|c|c|}
\hline \multirow[t]{2}{*}{ Species } & \multicolumn{6}{|c|}{ Larvae } & \multicolumn{6}{|c|}{ Adults } \\
\hline & LAM & LIN & PAN & UST & No. & $\%$ & LAM & LIN & PAN & UST & No. & $\%$ \\
\hline Aedes (Stegomyia) albopictus & 30 & 4 & 57 & 0 & 91 & 6.5 & 49 & 1 & 19 & 1 & 70 & 27.8 \\
\hline Aedes (Ochlerotatus) sp. & 0 & 0 & 3 & 0 & 3 & 0.2 & 0 & 0 & 0 & 0 & 0 & 0.0 \\
\hline Aedes (Ochlerotatus) mariae & 0 & 55 & 65 & 32 & 152 & 11.4 & 0 & 0 & 0 & 3 & 3 & 1.4 \\
\hline Aedes (Ochlerotatus) zammitii & 51 & 0 & 0 & 0 & 51 & 3.6 & 8 & 0 & 0 & 0 & 8 & 3.1 \\
\hline Culex (Culex) laticinctus & $53^{*}$ & 115 & 0 & 22 & 190 & 13.7 & 4 & 3 & 0 & 0 & 7 & 2.9 \\
\hline Culex (Culex) pipiens & 164 & 0 & 104 & 55 & 323 & 23.4 & 125 & 0 & 16 & 16 & 157 & 62.5 \\
\hline Culiseta (Allotheobaldia) longiareolata & $260^{*}$ & $118^{*}$ & 28 & $163^{*}$ & 569 & 41.2 & 1 & 0 & 2 & 3 & 6 & 2.3 \\
\hline Total & 558 & 292 & 257 & 272 & 1379 & 100 & 187 & 4 & 37 & 23 & 251 & 100 \\
\hline
\end{tabular}

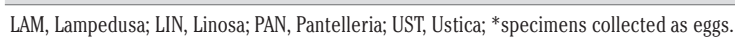

Table 3. Relative abundance of mosquito species recorded in larval habitats on the islands of Lampedusa, Linosa, Pantelleria and Ustica.

\begin{tabular}{|c|c|c|c|c|c|c|c|c|c|c|c|}
\hline $\begin{array}{l}\text { Mosquito species (below) and } \\
\text { related positive larval breeding } \\
\text { site (on the right) found in } \\
\text { each island }\end{array}$ & $\begin{array}{l}\text { Flower I } \\
\text { pot/ } \\
\text { cemetery }\end{array}$ & $\begin{array}{l}\text { Plastic } \\
\text { jerry } \\
\text { y can }\end{array}$ & $\begin{array}{r}\text { Bucket Wheelie } \\
\text { dustbin }\end{array}$ & $\begin{array}{c}\text { Plastic } \\
\text { tank }\end{array}$ & $\begin{array}{l}\text { Dog } \\
\text { bowl }\end{array}$ & $\begin{array}{l}\text { Animal } \\
\text { water } \\
\text { trough }\end{array}$ & $\begin{array}{l}\text { Brick- } \\
\text { tank } \\
\text { for rain } \\
\text { water }\end{array}$ & Manhole & $\begin{array}{c}\text { Water } \\
\text { pit }\end{array}$ & $\begin{array}{l}\text { Sea } \\
\text { rock } \\
\text { pools }\end{array}$ & $\begin{array}{l}\text { Natural } \\
\text { water } \\
\text { receptacles }\end{array}$ \\
\hline $\begin{array}{l}\text { Lampedusa Island } \\
\text { Culex (Culex) pipiens } \\
\text { Culex(Culex) laticinctus } \\
\text { Aedes (Stegomyia) albopictus } \\
\text { Culiseta (Allotheobaldia) longiareolata } \\
\text { Aedes (Ochlerotatus) zammitii }\end{array}$ & $\begin{array}{c}+++ \\
+\end{array}$ & + & $\begin{array}{l}+ \\
+ \\
+\end{array}$ & $\begin{array}{l}+ \\
++\end{array}$ & & $\begin{array}{c}+ \\
+++\end{array}$ & & & ++ & +++ & \\
\hline $\begin{array}{l}\text { Linosa Island } \\
\text { Culex(Culex) laticinctus } \\
\text { Aedes (Stegomyia) albopictus } \\
\text { Culiseta (Allotheobaldia) longiareolata } \\
\text { Aedes (Ochlerotatus) mariae }\end{array}$ & + & + & $\begin{array}{l}++ \\
++ \\
++\end{array}$ & ++ & & & +++ & & & +++ & \\
\hline $\begin{array}{l}\text { Pantelleria Island } \\
\text { Culex (Culex) pipiens } \\
\text { Culex (Culex) laticinctus } \\
\text { Aedes (Stegomyia) albopictus } \\
\text { Culiseta (Allotheobaldia) longiareolata } \\
\text { Aedes (Ochlerotatus) mariae } \\
\text { Aedes (Ochlerotatus) sp. }\end{array}$ & $\begin{array}{l}+ \\
+\end{array}$ & & $\begin{array}{c}+ \\
+ \\
++ \\
++ \\
+++\end{array}$ & ++ & + & $\begin{array}{l}+ \\
++\end{array}$ & & $\begin{array}{l}+ \\
+ \\
+\end{array}$ & & +++ & $\begin{array}{l}+ \\
+ \\
+\end{array}$ \\
\hline $\begin{array}{l}\text { Ustica Island } \\
\text { Culex(Culex) pipiens } \\
\text { Culex (Culex) laticinctus } \\
\text { Aedes (Stegomyia) albopictus } \\
\text { Culiseta (Allotheobaldia) longiareolata } \\
\text { Aedes (Ochlerotatus) mariae }\end{array}$ & & & $\begin{array}{l}++ \\
++ \\
+++\end{array}$ & $\begin{array}{l}+ \\
+ \\
+++\end{array}$ & & ++ & +++ & & & +++ & ++ \\
\hline
\end{tabular}

+ present; ++ common; +++ abundant; *basin with saltwater. 
them as Ae. zammitii (MN847666-77). No intraspecific variability was detected among sequences generated which showed $98.79 \%$ identity with a mosquito from Turkey or Northern Cyprus (KX009742). With regard to the other islands, only a portion of mosquitoes belonging to the Ae. mariae complex was analyzed molecularly, generating a novel 369-bp amplicon for 5 specimens collected in Linosa (MN847633-7); 10 from Pantelleria (MN847638-47) and 18 from Ustica (MN847648-65). All ITS-2 amplicons showed the same sequence that identified specimens as Ae. mariae (Table 1). The amplification and sequencing of ITS-2 marker was applied also for two out of three II instar larvae of Aedes genus, collected in the Specchio di Venere Lake, Ustica, generating a 373-bp fragment (MN153029-30). No intraspecific variability was detected, and the two sequences showed low identity with ITS2 from other Aedes species, remaining unidentified. In particular, the two ITS2-sequences showed $83.03 \%$ identity with Aedes detritus (MG232616), 83.85\% with Aedes caspius (KP642746), 83.27\% with Aedes dorsalis (MG232618), 81.89\% with Aedes mariae from Pantelleria, 79.32\% with Aedes communis (KF535019), and 79.27\% with Aedes zammitii from Lampedusa.

The sequencing of the mitochondrial cytochrome c oxidase subunit I gene (COI) from Culex mosquitoes allowed us to distinguish molecularly $C x$. laticinctus from $C x$. pipiens, corroborating the morphological identification of these two mosquito species. A 701-bp region of the COI from 3 mosquitoes collected on Lampedusa was sequenced (MN850535-7), identifying them as $C x$. laticinctus. No intraspecific variability was detected, and the resulting sequences were compared with those available in GenBank, showing $99.73 \%$ identity with a specimen from Malta (MF059294), 99.14\% identity with specimens from Turkey (KJ012087-95), and $98.72 \%$ identity with a specimen from the United Arab Emirates.
A 709-bp region of the COI from 5 mosquitoes from Lampedusa (MN850549-3) and 3 from Pantelleria (MN850554-6) was sequenced. The BLASTn search identified these sequences as $C x$. pipiens and no intraspecific variability was detected among them. In order to compare $C x$. pipiens mosquitoes from different Mediterranean islands, additional sequences were generated in this study, 3 from Malta (MN850557-9) and 3 from Rhodes (MN850560-2), respectively. All sequences but one showed 100\% identity with Sicilian specimens, whereas one specimen from Rhodes was characterized by a single silent variable site ( $G \leftrightarrow A$ transition at position 123).

The newly described sequences from this study were deposited in GenBank under the accession numbers MN153029-30; MN847633-77; MN850535-7; MN850549-62.

Data collected represent the first entomological enquiry focused on mosquito fauna from the Pelagie islands, Pantelleria and Ustica. In the first survey of July on Lampedusa, the semi-arid environment made the research of mosquitoes difficult due to the scarcity of water. A brief consultation with the residents allowed us to discover the rare, wet places and the scarce freshwater receptacles suitable for mosquitoes, which were often placed in underground locations or in private gardens. The findings show that although limited, the few available water resources enabled mosquito occurrence. In particular the presence of Ae. albopictus (Di Luca et al., 2017), Cx. pipiens and $C x$. laticinctus was widely detected on the islands, although relevant densities were recorded only locally, especially with respect to Ae. albopictus (Di Luca et al., 2017).

Culex laticinctus is a species poorly known in its biology and can often be confused with $C x$. pipiens, being morphologically a very similar species. However, this study confirmed the COI target as a useful molecular marker to distinguish both species. Cx. laticinctus is known to be able to lay eggs in a wide range of natural or artificial

Table 4. Relative abundance of mosquito species recorded as adults in resting sites on the islands of Lampedusa, Linosa, Pantelleria and Ustica.

\begin{tabular}{|c|c|c|c|c|c|c|c|}
\hline $\begin{array}{l}\text { Mosquito species (below) and Cemetery } \\
\text { related positive adult resting } \\
\text { site (on the right) found in } \\
\text { each island }\end{array}$ & $\begin{array}{l}\text { Public } \\
\text { garden }\end{array}$ & $\begin{array}{l}\text { Urban } \\
\text { context }\end{array}$ & $\begin{array}{c}\text { Rural } \\
\text { context }\end{array}$ & $\begin{array}{l}\text { Vetation } \\
\text { in urban } \\
\text { context }\end{array}$ & $\begin{array}{l}\text { Vegetation } \\
\text { in rural } \\
\text { context }\end{array}$ & $\begin{array}{l}\text { Rock } \\
\text { beach/rock } \\
\text { seaside }\end{array}$ & $\begin{array}{l}\text { Animal } \\
\text { shelter }\end{array}$ \\
\hline $\begin{array}{l}\text { Lampedusa Island } \\
\text { Culex (Culex) pipiens } \\
\text { Culex(Culex) laticinctus } \\
\text { Aedes (Stegomyia) albopictus } \\
\text { Culiseta (Allotheobaldia) longiareolata } \\
\text { Aedes (Ochlerotatus) zammitii }\end{array}$ & $\begin{array}{c}+ \\
+++ \\
+++\end{array}$ & $\begin{array}{l}+ \\
++ \\
+\end{array}$ & ++ & ++ & $\begin{array}{l}+ \\
+ \\
+ \\
+\end{array}$ & ++ & $\begin{array}{l}++ \\
+ \\
+\end{array}$ \\
\hline $\begin{array}{l}\text { Linosa Island } \\
\text { Culex(Culex) laticinctus } \\
\text { Aedes (Stegomyia) albopictus } \\
\text { Culiseta (Allotheobaldia) longiareolata } \\
\text { Aedes (Ochlerotatus) mariae }\end{array}$ & & + & + & + & + & & \\
\hline $\begin{array}{l}\text { Pantelleria Island } \\
\text { Culex (Culex) pipiens } \\
\text { Culex (Culex) laticinctus } \\
\text { Aedes (Stegomyia) albopictus } \\
\text { Culiseta (Allotheobaldia) longiareolata } \\
\text { Aedes (Ochlerotatus) mariae }\end{array}$ & & & + & & + & & + \\
\hline $\begin{array}{l}\text { Ustica Island } \\
\text { Culex(Culex) pipiens } \\
\text { Culex (Culex) laticinctus } \\
\text { Aedes (Stegomyia) albopictus } \\
\text { Culiseta (Allotheobaldia) longiareolata } \\
\text { Aedes (Ochlerotatus) mariae }\end{array}$ & & + & + & & & + & + \\
\hline
\end{tabular}

+ present; ++ common; +++ abundant. 
water receptacles, often in association with $C x$. pipiens. This situation is confirmed by our observation also on Lampedusa where $C x$. laticinctus results in being widely present even if not locally abundant and often sharing the same breeding sites with $C x$. pipiens that was more abundant. $C x$. laticinctus is reported to be distributed in the Mediterranean Region, the Arabian Peninsula, Iran, northeastern and northwestern Africa and the Canary Islands. In Italy its occurrence is reported in several records for southern and insular areas (Romi et al., 1997; Stojanovich \& Scott, 1997; Becker et al., 2020). In addition, a recent study found this species sporadically in Emilia Romagna, Puglia, Calabria and Sicily (Mancini et al., 2017), supporting our findings. On Lampedusa, many small artificial water containers inspected were effective larval breeding sites, such as flowers pots, filled with water, located in the Sanctuary and in the cemetery, which were almost always positive to the mosquito presence. Intriguingly, such water containers that elsewhere represent typical larval breeding sites for Ae. albopictus (O'Meara et al., 1992; Vezzani, 2007) on Lampedusa were colonized by $C x$. pipiens in the Sanctuary and by $C x$. laticinctus in the cemetery (Table 3 ). The only kind of potential breeding site free of mosquito larvae was a large (>1000 liters) drinking trough for goats where the frequent water replacement prevented the larval development. The occurrence of Cs. longiareolata was widespread on Lampedusa, where buckets and water troughs for livestock in vegetable gardens, farms and domestic hen houses were the main larval breeding sites. Ae. zammitii, identified morphologically and molecularly, was abundant in colonized rock pools that are typical along the southeastern coast of the island, and its occurrence confirmed a previous, but dated record (Coluzzi et al., 1974). The second survey on Lampedusa, carried out in late October 2015, confirmed the mosquito fauna composition, with the exception of Cs. longiareolata, and with Ae. albopictus occurring in lower density than July. Also on this occasion, Ae. zammitii was frequently found in the saltwater of many rock pools inspected. During this second survey, Linosa was visited in only 6 hours, a timelimit imposed by the ferry schedules. Here, two larvae of $A e$. albopictus were found in two different flower pots in the small cemetery. In a large vegetable garden surrounding a house, an adult of the Asian tiger mosquito, emerging from a plastic tank containing still water, was collected. In the same site many larvae and egg-rafts belonging to $C s$. longiareolata and $C x$. laticinctus were collected in a large brick-tank, used for the collection of rainwater, and in various water receptacles, mainly plastic buckets. Other Ae. albopictus larvae were found in a small tank used for the collection of water below a gutter in the village of Linosa. Besides peridomestic areas, $C x$. laticinctus was also found in the countryside of the island, in particular a male of this species was caught in a small hole in a tufa rock wall, a cool refuge during the hottest hours of the day. No $C x$. pipiens specimens were found on this island. The lack of this common species, widely occurring on the other islands, was probably due to the scarcity of water resources, both natural and artificial, or much more likely due to the short time we spent on the island, that prevented us from finding this species. In Contrada dei Faraglioni locality, along the seashore of the island several rock pools, differing in size and capacity, were inspected showing the presence of Ae. mariae, unlike the nearby island of Lampedusa where we found Ae. zammitii. On Pantelleria, mosquitoes were mainly collected at larval stage, at a not so high density due to the late season and to the strong wind which blows constantly and profoundly characterizes life on this island. The presence of Ae. albopictus was highlighted in several locations on the island (Di Luca et al., 2017). Ae. mariae was found as larvae in two saltwater rock pools, both in the northern and in the southern part of the island. Being the only lake occurring on these islands and for its particular nature (high salt concentration and a temperature of more than $30^{\circ} \mathrm{C}$ ), the brackish and thermal Specchio di Venere Lake was thoroughly inspected. Three larvae belonging to Aedes genus were collected 3 metres from the shore, in less than $10 \mathrm{~cm}$ of water where aquatic vegetation was abundant. The morphological identification was very difficult and controversial because these larvae were second instar. Even if the characters were incomplete because of their age, their diagnosis excluded that the larvae belonged to the Ae. mariae complex. Alternatively, although some characters appeared inconsistent (according to Gutsevich et al., 1974; Stojanovich \& Scott, 1997; Romi et al., 1997), these specimens could belong to Ae. detritus, another species not so different from the Ae. mariae complex, found on the Malta Archipelago (Schaffner et al., 2010), which is quite far from Pantelleria but similar to the Sicilian islands from a geographical aspect. In addition, molecularly these three larvae did not belong to any of the following species: Ae. detritus, Ae. caspius, Ae. dorsalis, Ae. communis, Ae. mariae and Ae. zammitii, remaining therefore unidentified. Certainly, this finding needs to be further investigated on Pantelleria. On Ustica, Cs. longiareolata was the species most frequently observed. It was found on the four small farms visited, all of which hosted at least one hen house, confirming the ornithophilic behavior of Cs. longiareolata (Romi et al., 1997). Such circumstances were common during each entomological survey carried out on all the islands, where the species was mainly found as egg-rafts in buckets, tanks and bowls. Also $C x$. pipiens and $C x$. laticinctus were found on Ustica in similar environmental conditions, and particularly on Pantelleria, where hens and poultry were generally bred. All these three species in fact share the ability to colonize different types of water receptacles (Senevet \& Andarelli, 1959) and, with the exception of $C x$. laticinctus, whose biology has barely been studied, are known to be used to feeding primarily on birds. The extensive finding of Cs. longiareolata and Cx. pipiens is consequent to the abundant presence of artificial breeding sites in peridomestic areas. The low number of Culiseta specimens caught in the traps may be due to the low attractivity of $\mathrm{CO}_{2}$ for this species, as often observed in similar studies (Schaffner et al., 2010). Unlike the entomological survey conducted on the Malta archipelago (Schaffner et al., 2010), the only mosquito species not found in our study was Culex perexiguus, a taxon never reported in Italy up to now. Among the collected species, Ae. albopictus and Cx. pipiens are considered mosquito species of health concern. Ae. albopictus is a peridomestic and anthropophilic species, that was responsible in 2007 for the first European outbreak of chikungunya in the Emilia Romagna Region, (Rezza et al., 2007) and then in 2017 in Lazio and Calabria Regions (Venturi et al., 2017; Riccardo et al., 2019). Moreover this species has been shown experimentally to be a competent vector of at least 26 arboviruses, including West Nile virus (WNV) (Paupy et al., 2009; Fortuna et al., 2015) and Zika virus (ZIKV) (Chouin-Carneiro et al., 2016; Di Luca et al., 2016). Cx. pipiens and the mosquitoes belonging to the Culex pipiens complex are considered to be involved in the transmission of a series of pathogens, including West Nile virus (WNV) responsible for a febrile and a neuro-invasive disease that can affect horses and humans (Turrell, 2012). In Italy WNV is endemic since 2008 starting from North East but in 2018, WNV transmission in endemic Provinces in Italy a noteworthy outbreak rise up with higher human case counts of confirmed infection compared with previous years (Riccardo et al., 2018). Furthermore, the potential vector competence of $C x$. laticinctus for pathogens is unknown at date, even if the whole genus Culex is known to be able to maintain the natural cycle of WNV (Campbell et al., 2002). Even if no data are available about the health concern represented by Ae. mariae and Ae. zammitii, it is worth considering that these species are annoying during the daytime along the rocky sea coasts, thus causing an impact on tourist activities when the mosquito densities are high. 


\section{Conclusions}

In general, all entomological surveys carried out on the four, minor Sicilian islands represent the first inquiry focusing on the local mosquito fauna carried out so far.

With the definition of the first checklist of the mosquito species on these islands, we have highlighted the widespread occurrence of Cx. laticinctus whose distribution in Italy is still not well known and whose ecology and habits are poorly studied (Severini et al., 2009; Becker et al, 2010). On Pantelleria, Ustica and Linosa the presence of Ae. mariae from rock-pools facing the sea is a new record with regard to this species, whereas in Lampedusa we found Ae. zammitii confirming its presence on this island. Moreover, we have shown the unusual habits of $C x$. pipiens with regard to larval breeding sites in conditions of scarcity of water and, for the first time, Ae. albopictus was reported on these islands, including Lampedusa where the species has the southernmost limit of the European distribution (Di Luca et al., 2017; Toma et al., 2017). On Pantelleria, three larvae of Aedes mosquito were not identified at specific level leaving this finding unsolved.

Finally, during the whole activity, the support from the local Authorities and the collaboration of the inhabitants were crucial to the success of the investigation in allowing us access to their properties and in identifying the most available places to find mosquitoes.

\section{References}

BECKER N., PETRIĆ D., ZGOMBA M., BOASE C., MADON M., DAHL C., KAISER A., 2010 - Mosquitoes and their Control. Second Edition. - Springer, Heidelberg, Germany, 577 pp.

CAMPBELL G.L., MARFIN A.A., LANCIOTTI R.S., GUBLER D.J., 2002 - West Nile virus. - Lancet Inf. Dis. 2: 519-529.

CHOUIN-CARNEIRO T., VEGA-RUA A., VAZEILLE M., YEBAKIMAA., GIROD R., GOINDIN D., 2016. - Differential susceptibilities of Aedes aegypti and Aedes albopictus from the Americas to Zika virus. - PLoS Negl. Trop. Dis. 10(3): e0004543

COLUZZI M., SABATINI A., BULLINI L., RAMSDALE C., 1974 - Nuovi dati sulla distribuzione delle specie del complesso mariae del genere Aedes. - Riv. Parassitol. 35(4): 321-330.

D’ALESSANDRO G., SACCÀ G. 1967 - Anopheles (Myzomyia) sergentii Theobald nell'isola di Pantelleria e sua probabile implicazione nella trasmissione di alcuni casi di malaria. Parassitologia 9: 69-72.

DI LUCA M., TOMA L., SEVERINI F., ROMI R., 2005. Identificazione delle specie del complesso Ochlerotatus mariae attra verso l'analisi dell'ITS-2. - Proceedings of the XX C.N.I.E. Congress, Perugia-Assisi 13-18 June, 2005. 334.

DI LUCA M., SEVERINI F., TOMA L., BOCCOLINI D., ROMI R., REMOLI M.E. SABBATUCCI M., RIZZO C., VENTURI G., REZZA G., FORTUNA C., 2016. - Experimental studies of susceptibility of Italian Aedes albopictus to Zika virus. - Euro Surveill. 21(18): pii30223.

DI LUCA M., TOMA L., SEVERINI F., BOCCOLINI D., D'AVOLA S., TODARO D., STANCANELLI A., ANTOCI F., LA RUSSA F., CASANO S., SOTERA S.D., CARRAFFA E., VERSTEIRT V., SCHAFFNER F., ROMI R., TORINA A., 2017 - First record of the invasive mosquito species Aedes (Stegomyia) albopictus (Diptera: Culicidae) on the southernmost Mediterranean islands of Italy and Europe. Parasit. Vectors. 10: 543.

FOLMER O., BLACK M., HOEH W., LUTZ R., VRIJENHOEK R., 1994. - DNA primers for amplification of mitochondrial cytochrome c oxidase subunit I from diverse metazoan invertebrates. - Mol. Mar. Biol. Biotechnol. 3: 294-9.

FORTUNA C., REMOLI M.E., SEVERINI F., DI LUCA M., TOMA L., FOIS F., BUCCI P., BOCCOLINI D., ROMI R., CIUFOLINI M.G., 2015. - Evaluation of vector competence for West Nile Virus in italian Stegomyia Albopicta (=Aedes Albopictus) mosquitoes. - Med. Vet. Entomol. 29: 430-433.

GATT P., DEEMING J.C., SCHAFFNER F., 2009 - First record of Aedes (Stegomyia) albopictus (Skuse) (Diptera:Culicidae) in Malta. - Eur. Mosq. Bull. 27: 56-64.

GUTSEVICH A.V., MONCHADSKII A.S., SHTAKEL'BERG A.A., 1974 - Fauna of the USSR. Diptera - Mosquitoes, Family Culicidae. Israel Program for Scientific Translations. Accademy of Sciences of the USSR, 3(4), 408 pp.

MANCINI G., MONTARSI F., CALZOLARI M., CAPELLI G., DOTTORI M., RAVAGNAN S., LELLI D., CHIARI M., SANTILLI A., QUAGLIA M., FEDERICI V., MONACO F., GOFFREDO M., SAVINI G., 2017 - Mosquito species involved in the circulation of West Nile and Usutu viruses in Italy. - Vet. Ital. 53(2): 97-110.

MARINUCCI M., ROMI R., MANCINI P., DI LUCA M., SEVERINI C., 1999 - Phylogenetic relationships of seven palearctic members of the maculipennis complex inferred from ITS2 sequence analysis. - Ins. Mol. Biol. 8: 469-480.

O'MEARA G.F., GETTMAN A.D., EVANS L.F., SCHEEL F.D., 1992 - Invasion of cemeteries in Florida by Aedes albopictus. J. Am. Mosq. Control. 8: 1-10.

PAUPY C., DELATTE H., BAGNY L., CORBEL V., FONTENILLE D., - 2009. Aedes albopictus, an arbovirus vector: from the darkness to the light. - Microb. Infect. 11: 1177-1185.

PIERDOMINICI G., ROMI R., MASSA A., MORETTI R., 1984 Tecniche per l'allevamento di insetti di interesse sanitario e procedure correnti per il mantenimento di un insettario. Rapporti Istisan 84/19. Istituto Superiore di Sanità, Roma.

REZZA G., NICOLETTI L., ANGELINI R., ROMI R., FINARELLI A.C., PANNING M., et al., 2007 - Infection with chikungunya virus in Italy: an outbreak in a temperate region. Lancet. 370(9602): 1840-6.

RICCARDO F., MONACO F., BELLAA., SAVINI G., RUSSO F., CAGARELLI R., DOTTORI M., RIZZO C., VENTURI G., DI LUCA M., PUPELLA S., LOMBARDINI L., PEZZOTTI P., PARODI P., MARAGLINO F., NANNI COSTA A., LIUMBRUNO G.M., REZZA G., the working group, 2018 An early start of West Nile virus seasonal transmission: the added value of One Heath surveillance in detecting early circulation and triggering timely response in Italy, June to July 2018. - Euro Surveill. 23(32): 1800427..

RICCARDO F., VENTURI G., DI LUCA M., DEL MANSO M., SEVERINI F., ANDRIANOU X., FORTUNA C., REMOLI M.E., BENEDETTI E., CAPORALI M.G., FRATTO F., MIGNUOLI A.D., RIZZO L., DE VITO G., DE GIORGIO V., SURACE L., VAIRO F., ANGELINI P., RE M.C., AMENDOLA A., FIORENTINI C., MARSILI G., TOMA L., BOCCOLINI D., ROMI R., PEZZOTTI P., REZZA G., RIZZO C., 2019 - Secondary Autochthonous Outbreak of Chikungunya, Southern Italy, 2017. - Emerg. Infect. Dis. 25: 2093 - 2096.

ROMI R., SABATINELLI G., PONTUALE G., 1997 - Le zanzare italiane: generalità e identificazione degli stadi preimaginali (Diptera, Culicidae). - Fragmenta Entomol. 29: 1-141. 
SCHAFFNER F., GATT P., MALL S., MAROLI M., SPITERI G., MELILLO T., ZELLER H., 2010 - Mosquitoes in Malta: preliminary entomological investigation and risk assessment for vector-borne diseases (Diptera: Culicidae). - Bull. Entomol. Soc. Malta. 3: 41-54.

SCHAFFNER F., ANGEL G., GEOFFROY B., HERVY J.P., RHAIEM A., BRUNHES J., 2001 - The mosquitoes of Europe. An identification and training programme. - IRD Éditions \& EID Méditerrannée, Montpellier (CD-ROM).

SENEVET G., ANDARELLI L. 1959 - Les moustiques de l'Afrique $\mathrm{du}$ nord et du bassin mediterranéen: le genre Culex, Uranotaenia, Theobaldia, Orthopodomyia, et Mansonia. Encyclopédie entomologique, - Paul Lechevalier, Paris, 384 pp.

SEVERINI F., TOMA L., DI LUCA M., ROMI R., 2009 - Le zanzare italiane: generalità e identificazione degli adulti (Diptera: Culicidae). - Fragmenta Entomol. 41: 213-372.

STOJANOVICH C.J., SCOTT H.G., 1997 - Mosquitoes of the Italian biogeographic area which includes the Republic of Malta, the French Island of Corsica and all Italy except the FarNorthern Provinces. Published by the Authors, Stojanovich \& Scott, USA, 200 pp.
TOMA L., TOMA F., PAMPIGLIONE G., GOFFREDO M., SEVERINI F., DI LUCA M., 2017 - First record of Aedes albopictus (Skuse, 1894) (Diptera; Culicidae) from three islands in the Tyrrhenian Sea (Italy). - J. Am. Mosq. Control. 35: 25-28.

TURELL M.J. 2012. - Members of the Culex pipiens complex as vectors of viruses. J. Am. Mosq. Control. 28(4): 123-126.

VENTURI G., DI LUCA M., FORTUNA C., REMOLI M.E., RICCARDO F., SEVERINI F., TOMA L., DEL MANSO M., BENEDETTI E., CAPORALI M.G., AMENDOLA A., FIORENTINI C., DE LIBERATO C., GIAMMATTEI R., ROMI R., PEZZOTTI P., REZZA G., RIZZO C., 2017. Detection of a chikungunya outbreak in Central Italy, August to September 2017. - Euro Surveill. 22(39): pii=17-00646.

VEZZANI D., 2007 - Review: Artificial container-breeding mosquitoes and cemeteries: a perfect match. - Trop. Med. Int. Health. 12(2): 299-313..

WILKERSON R.C., LINTON Y.-M., FONSECA D., SCHULTZ T.R., PRICE D.C., STRICKMAN D.A., 2015 - Making Mosquito Taxonomy Useful: A Stable Classification of Tribe Aedini that Balances Utility with Current Knowledge of Evolutionary Relationships. - PLoS One DOI:10.1371/journal.pone.0133602, 26 pp. 